\title{
Changes in the human visual evoked potential caused by the anticholinergic agent hyoscine hydrobromide: comparison with results in Alzheimer's disease
}

\author{
AAA BAJALAN, * CE WRIGHT, VJ VANDER VLIET \\ From the Clinical Neurophysiology Unit, Department of Vision Sciences, University of Aston, Birmingham, and \\ Department of Neurophysiology, ${ }^{*}$ Hill Royal Infirmary, Hull, UK
}

SUMMARY The anticholinergic drug hyoscine hydrobromide produced a slowing of the P2 and N3 components of the flash visual evoked potential (VEP) in young normals but did not affect the pattern reversal VEP. These results, which are similar to those found in Alzheimer's disease, could be explained by an underlying defect of the cholinergic system.

Drugs that block central acetylcholine muscarinic receptors have long been known to disrupt cognitive function and induce transient amnesia in humans. ${ }^{1}$ Low doses of the centrally active muscarinic receptor blocker hyoscine hydrobromide have been found to impair memory storage in normal subjects, but do not affect immediate memory. ${ }^{2-7}$ The memory storage defect can be improved by administration of the cholinergic agonist arecholine ${ }^{6}$ or the anticholinesterase physostigmine, but not by the psychostimulant amphetamine ${ }^{5}$ indicating that the hyoscine has a specific effect on cholinergic neurons. At the same time as the amnestic effects, the electroencephalogram (EEG) shows a replacement of normal alpha activity by slower, low amplitude waves of $5-8 \mathrm{~Hz}$, and inhibition of the EEG arousal response to a single flash of light. ${ }^{2}$ Such findings have led to the proposition that cholinergic neurotransmitters are essential for the functioning of the reticular arousal system and the storage of recent memory. ${ }^{8}$

The similarity between these effects in normals and the memory defects and EEG slowing found in Alzheimer's disease have led to the use of the pharmacological effects of hyoscine hydrobromide as a model for Alzheimer's disease. Indeed, experimental work with hyoscine hydrobromide provided the first indication that defects of the cholinergic systems may underlie the amnestic symptoms of Alzheimer's disease. ${ }^{5}$

In recent years, much evidence has accumulated to

Address for reprint requests: Dr AAA Bajalan, Department of Neurophysiology, Hull Royal Infirmary, Analaby Road, Hull, HU3 2JZ, UK

Received 15 February 1985 and in revised form 22 May 1985. Accepted 28 May 1985 suggest an underlying cholinergic deficit in Alzheimer's disease. Necropsy brain specimens show histopathological evidence of a selective loss of cholinergic neurons in this condition. ${ }^{9}$ Biochemical evidence shows cortical reduction of the presynaptic enzyme choline acetyltransferase (ChAT) which synthesises the neurotransmitter acetylcholine (ACh).$^{10-15}$ These reductions are most prominent in the hippocampus, parietal and temporal cortex. ${ }^{81316}$ Reduction of the rate of acetylcholine synthesis has also been found in biopsy samples from the temporal lobe of patients with Alzheimer's disease. ${ }^{17}$ The reduction in cortical ChAT at necropsy correlates with both plaque density and the severity of intellectual impairment in Alzheimer's disease. ${ }^{18}$ Indeed, it has been shown that cholinergic innervation is important in the evolution of neuritic plaques. ${ }^{9}$

The concentration of cortical muscarinic receptors is not reduced in Alzheimer's disease, indicating that the deficit is presynaptic. ${ }^{1219}$ Current research on primates indicates that the majority of cholinergic presynaptic axons in the cortex originate in subcortical nuclei such as the nucleus basalis of Meynert and the diagonal band of Broca. ${ }^{920}$ Postmortem studies of human brains with Alzheimer's disease have shown a reduction of $\mathrm{ChAT}^{8}$ and the neuronal population ${ }^{921}$ in the nucleus basalis of Meynert and the diagonal band of Broca, but not in the adjacent putamen and globus pallidus. These results indicate that the reduction in ChAT activity is due to cell loss and degeneration rather than to an alteration of enzyme activity within a surviving neuronal population. ${ }^{8}$

Visual evoked potential (VEP) studies in our laboratory have shown that patients with Alzheimer's disease have the unusual combination of a delayed flash 
major positive (P2) component and a pattern VEP of normal latency. ${ }^{22}$ The amplitude of the flash P2 component was significantly higher than that of normal elderly controls, but this was not significant when compared with a patient control group with affective disorders but no evidence of dementia. It appears, therefore, that the dementing process produces the effect on the flash P2 latency rather than on the amplitude. It was suggested that this unusual finding might reflect either different cortical sources of the flash and pattern VEP, or the effect of a specific neurotransmitter defect. In view of the similarity between the pharmacological effects of hyoscine hydrobromide and clinical findings in patients with Alzheimer's disease, we decided to investigate the effect of hyoscine hydrobromide on the VEP of normal controls. This study compared the flash and pattern reversal VEP in ten normal subjects before a subcutaneous injection of $0.6 \mathrm{mg}$ hyoscine hydrobromide, during the period of the maximum pharmacological effect of the drug, ${ }^{2}$ and 24 hours after the injection. Brainstem auditory evoked potentials (BAEPs) were also recorded as a neurophysiological assessment of the brainstem auditory pathways.

\section{Procedure}

The pattern reversal VEP was recorded first, followed by the flash VEP and BAEP. The evoked potientials were stored on a disc for later analysis. The first recordings were made at $1.30 \mathrm{pm}$ and took about 10 minutes. The subcutaneous injection of $0.6 \mathrm{mg}$ hyoscine hydrobromide was given at $2.00 \mathrm{pm}$ and the subject allowed to rest for an hour while the drug took effect. The evoked potientials were then recorded at $3.00,3.30,4.00,4.30$ and $5.00 \mathrm{pm}$, to monitor the peak effect of the drug and subsequent recovery. The procedure was first carried out on a "control" afternoon, with no drug administration, so that any effects of fatigue, boredom or diurnal variation over the 4 hours could be accounted for. In the case of female subjects, the control and hyoscine afternoons were exactly 4 weeks apart, so that EEG changes connected with the montly cycle did not influence the results. An additional recording was made 24 hours after the administration of the hyoscine to ensure that the evoked potentials had returned to normal.
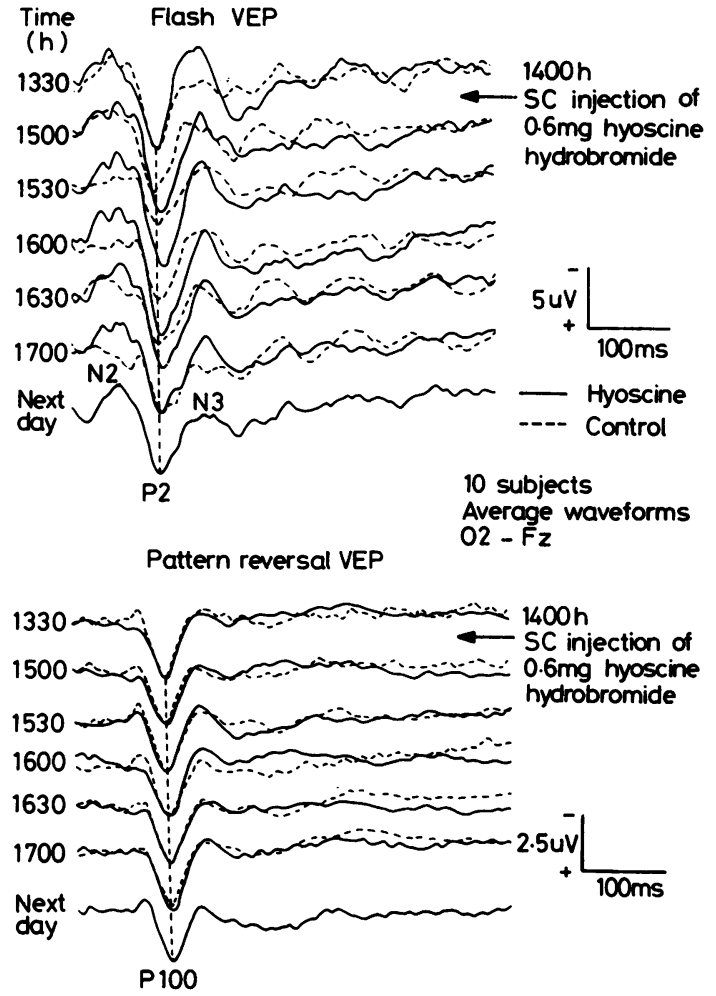

Fig 1 Group average waveforms of the 10 subjects. The flash VEP shows an increase in P2 and N3 latency and an increase in N2-P2 amplitude following the injection of hyoscine. The pattern reversal VEP is unchanged.

The subjects, with an age of 21-37 years (mean $27 \cdot 3 \pm$ $5 \cdot 1)$ participated in the study. They were all staff or postgraduates of the Clinical Neurophysiology Unit who were fully informed and in agreement with the purposes and methods to be used. The project was given approval by the Human Science Ethical Committee of the University.

The medically qualified member of the team administered the injection and was present throughout the afternoon in

Table 1 Latency of flash visual evoked potential

\begin{tabular}{|c|c|c|c|c|c|c|c|c|c|c|}
\hline Com & pponent & $1.30 \mathrm{pm}$ & $2.00 \mathrm{pm}$ & $3.00 \mathrm{pm}$ & $3.30 \mathrm{pm}$ & $4.00 \mathrm{pm}$ & $4.30 \mathrm{pm}$ & $5.00 \mathrm{pm}$ & Next Day & $\begin{array}{l}\text { Statistical } \\
\text { significance }\end{array}$ \\
\hline $\begin{array}{l}\text { N2 } \\
\text { P2 } \\
\text { N3 }\end{array}$ & $\begin{array}{l}\text { Control } \\
\text { Hyoscine } \\
\text { Control } \\
\text { Hyoscine } \\
\text { Control } \\
\text { Hyoscine }\end{array}$ & $\begin{array}{r}81.8 \pm 9.5 \\
80.4 \pm 10.6 \\
113.1 \pm 10.0 \\
114.3 \pm 9.9 \\
157.9 \pm 24.1 \\
154.1 \pm 13.0\end{array}$ & $\begin{array}{l}\text { Injection of } \\
\text { of } 0.6 \mathrm{mgm} \\
\text { hyoscine } \\
\text { hydrobromide } \\
\text { subcutaneously } \\
\text { (Experimental } \\
\text { day only) }\end{array}$ & $\begin{array}{r}78.9 \pm 11.1 \\
83.7 \pm 11.4 \\
113.9 \pm 10.9 \\
119.2 \pm 10.9 \\
150.0 \pm 13.0 \\
166.5 \pm 10.7\end{array}$ & $\begin{array}{c}82.2 \pm 12.9 \\
82.1 \pm 9.2 \\
115.5 \pm 8.8 \\
120.3 \pm 6.1 \\
153.9 \pm 13.6 \\
168.3 \pm 10.6\end{array}$ & $\begin{array}{l}81.2 \pm 14.7 \\
82.6 \pm 11.1 \\
117.2 \pm 7.4 \\
120.6 \pm 5.7 \\
154.9 \pm 14.9 \\
165.3 \pm 9.5\end{array}$ & $\begin{array}{r}81.4 \pm 12.8 \\
82.5 \pm 11.0 \\
114.8 \pm 10.4 \\
120.7 \pm 4.9 \\
158.1 \pm 14.5 \\
169.3 \pm 11.7\end{array}$ & $\begin{array}{l}82.5 \pm 12.5 \\
82.9 \pm 12.9 \\
115.9 \pm 8.6 \\
120.1 \pm 6.0 \\
155.4 \pm 17.4 \\
170.1 \pm 13.2\end{array}$ & $\begin{array}{l}\overline{79.3} \pm 10.9 \\
\overline{113.0} \pm 10.1 \\
\overline{160.6} \pm 15.1\end{array}$ & $\begin{array}{l}\text { NS } \\
p<0.05 \\
p<0.05\end{array}$ \\
\hline
\end{tabular}

Values represent mean latency and standard deviation, in $\mathrm{ms}$, for 10 subjects. 
Table 2 Latency of pattern reversal visual evoked potential

\begin{tabular}{|c|c|c|c|c|c|c|c|c|c|c|}
\hline Comp & onent & $1.30 \mathrm{pm}$ & $2.00 \mathrm{pm}$ & $3.00 \mathrm{pm}$ & $3.30 \mathrm{pm}$ & $4.00 \mathrm{pm}$ & $4.30 \mathrm{pm}$ & $5.00 \mathrm{pm}$ & Next Day & $\begin{array}{l}\text { Statistical } \\
\text { significance }\end{array}$ \\
\hline $\begin{array}{l}\text { N70 } \\
\text { P100 } \\
\text { N140 }\end{array}$ & $\begin{array}{l}\text { Control } \\
\text { Hyoscine } \\
\text { Control } \\
\text { Hyoscine } \\
\text { Control } \\
\text { Hyoscine }\end{array}$ & $\begin{array}{r}77.4 \pm 8.8 \\
72.4 \pm 8.9 \\
105.7 \pm 7.4 \\
103.6 \pm 10.2 \\
139.7 \pm 13.0 \\
139.0 \pm 10.5\end{array}$ & $\begin{array}{l}\text { Injection of } \\
0.6 \mathrm{mgm} \\
\text { hyoscine } \\
\text { hydrobromide } \\
\text { subcutaneously } \\
\text { (Experimental } \\
\text { day only) }\end{array}$ & $\begin{array}{r}75.0 \pm 8.7 \\
74.7 \pm 8.2 \\
105.0 \pm 6.2 \\
103.9 \pm 8.3 \\
137.5 \pm 9.5 \\
141.9 \pm 9.3\end{array}$ & $\begin{array}{r}76.5 \pm 5.6 \\
75.9 \pm 8.3 \\
105.0 \pm 6.9 \\
103.6 \pm 8.9 \\
138.8 \pm 10.1 \\
143.0 \pm 9.4\end{array}$ & $\begin{array}{c}77.4 \pm 8.8 \\
75.8 \pm 7.1 \\
106.2 \pm 7.5 \\
103.7 \pm 10.2 \\
138.1 \pm 10.2 \\
141.5 \pm 5.9\end{array}$ & $\begin{array}{c}74.5 \pm 7.7 \\
76.8 \pm 8.7 \\
100.0 \pm 7.5 \\
105.3 \pm 10.2 \\
137.9 \pm 12.5 \\
143.2 \pm 7.2\end{array}$ & $\begin{array}{c}76.6 \pm 9.3 \\
76.2 \pm 7.2 \\
103.6 \pm 7.2 \\
104.3 \pm 7.0 \\
140.3 \pm 13.6 \\
142.6 \pm 8.6\end{array}$ & $\begin{array}{l}-65.0 \pm 7.0 \\
\overline{103} \cdot 8 \pm 7.9 \\
\overline{144.7} \pm 18.5\end{array}$ & $\begin{array}{l}\text { NS } \\
\text { NS } \\
\text { NS }\end{array}$ \\
\hline
\end{tabular}

Values represent mean latency and standard deviation, in ms, for 10 subjects.

every case. To minimise the effects of drowsiness, the TV monitor was switched to broadcasting channels in between recordings and regular conversation was maintained. The peripheral effects of hyoscine are much smaller than those of atropine, but a refractive check was made to correct any latent hypermetropia and to ensure the pattern stimulus was clear at all times. (No difficulties with focusing were anticipated, as a TV screen at $150 \mathrm{~cm}$ only requires 0.67 dioptres of accommodation). To eliminate any possible diplopia caused by breakdown of a heterophoria, monocular stimulation was used throughout.

\section{Methods}

The evoked potentials were recorded using silver-silver chloride electrodes (resistance less than 5 kohms) and amplified and averaged by a Nicolet Pathfinder II.

Visual evoked potentials (VEPs) were recorded from occipital electrodes 02 and 01 , referred to $\mathrm{Fz}$ (International 10-20 system). One hundred sweeps were averaged by the computer, bandpass $0.5-70 \mathrm{~Hz}$. The flash stimulus was produced twice per second by a Grass PS22 stroboscope set at Intensity 2 (intensity of each flash $68 \mathrm{~cd} / \mathrm{m}^{2}$ per second). The pattern stimulus was a black and, white checkerboard presented on a Sony television screen and reversed twice per second by a Medelec visual stimulator. The mean luminance of the rectangular screen was $200 \mathrm{~cd} / \mathrm{m}^{2}$ and the field subtended at the eye was $7.6^{\circ} \times 10.2^{\circ}$. The check size was 56 minutes of arc and the contrast $74 \%$.

Brainstem auditory evoked potentials (BAEPs) were recorded between electrodes on the mastoid bones (Al and
A2) and the vertex electrode $\mathrm{Cz}$. The stimulus was a $0.1 \mathrm{~ms}$ click of alternating polarity presented to the right ear at 10 $\mathrm{Hz}$. The intensity was set at $70 \mathrm{~dB}$ above subjective threshold. Two thousand sweeps were averaged, with bandpass filters $30 \mathrm{~Hz}-3 \mathrm{kHz}$.

\section{Analysis of results}

The latencies and amplitudes of the most consistent components of the evoked potentials were determined. For the flash VEPs, the most consistent components were N2, P2 and N3 (fig 1). Very few of the subjects in this study showed the early flash components $\mathrm{N} 1$ and Pl. This is consistent with our previous study of the effect of age on the VEP ${ }^{24}$ which showed that the early components are not often found in the flash VEP of younger subjects, but they occur more frequently with increasing age. For the pattern reversal VEP the most consistent components were the predominant positive around $100 \mathrm{~ms}$, and the negatives around $70 \mathrm{~ms}$ and 140 ms (fig 1). Waves I-V of the BAEP were identified and Wave $\mathrm{V}$ included in the statistical analysis. Where waves were skewed or triphasic in configuration, the midpoint between the ascending and descending sides of the wave was determined.

No consistent differences between the hemispheres were observed. Therefore, for clarity and ease of analysis, the results from the right hemisphere alone are presented $(02-\mathrm{Fz}$ derivation for VEPs and A2-Cz for BAEPs). Analysis of variance tests were used to determine the statistical significance of the latency and amplitude changes, over time of day in hyoscine experiment date, and between hyoscine experiment and control dates. All individual results obtained at all different hours of recording were used in the calcu-

- Table 3 Latency of brainstem auditory evoked potential

\begin{tabular}{|c|c|c|c|c|c|c|c|c|c|c|}
\hline \multicolumn{2}{|c|}{ Component } & $\begin{array}{l}1.30 \mathrm{pm} \\
1.67 \pm 0.08\end{array}$ & 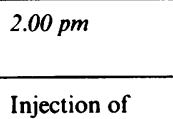 & $\frac{3.00 \mathrm{pm}}{1.69 \pm 0.11}$ & $\frac{3.30 \mathrm{pm}}{1.70 \pm 0.09}$ & $\begin{array}{l}4.00 \mathrm{pm} \\
1.68 \pm 0.07\end{array}$ & $\frac{4.30 \mathrm{pm}}{1.68 \pm 0.08}$ & $\frac{5.00 \mathrm{pm}}{1.64 \pm 0.08}$ & Next Day & $\begin{array}{l}\begin{array}{l}\text { Statistical } \\
\text { significance }\end{array} \\
\end{array}$ \\
\hline $\begin{array}{l}\text { I } \\
\text { II } \\
\text { III } \\
\text { IV } \\
\text { V }\end{array}$ & $\begin{array}{l}\text { Control } \\
\text { Hyoscine } \\
\text { Control } \\
\text { Hyoscine } \\
\text { Control } \\
\text { Hyoscine } \\
\text { Control } \\
\text { Hyoscine } \\
\text { Control } \\
\text { Hyoscine }\end{array}$ & $\begin{array}{l}1.67 \pm 0.08 \\
1.67 \pm 0.07 \\
2.27 \pm 0.12 \\
2.72 \pm 0.13 \\
3.73 \pm 0.15 \\
3.71 \pm 0.19 \\
4.94 \pm 0.27 \\
4.87 \pm 0.23 \\
5.54 \pm 0.20 \\
5.58 \pm 0.30\end{array}$ & $\begin{array}{l}\text { Injection of } \\
0.6 \mathrm{mgm} \\
\text { hyoscine } \\
\text { hydrobromide } \\
\text { subcutaneously } \\
\text { (Experimental } \\
\text { day only) }\end{array}$ & $\begin{array}{l}1.69 \pm 0.11 \\
1.69 \pm 0.16 \\
2.71 \pm 0.12 \\
2.74 \pm 0.18 \\
3.72 \pm 0.19 \\
3.74 \pm 0.21 \\
4.92 \pm 0.19 \\
4.87 \pm 0.22 \\
5.76 \pm 0.26 \\
5.59 \pm 0.28\end{array}$ & $\begin{array}{l}1.70 \pm 0.09 \\
1.65 \pm 0.13 \\
2.76 \pm 0.13 \\
2.75 \pm 0.16 \\
3.75 \pm 0.16 \\
3.73 \pm 0.18 \\
4.92 \pm 0.26 \\
4.95 \pm 0.22 \\
5.60 \pm 0.36 \\
5.58 \pm 0.28\end{array}$ & $\begin{array}{l}1.68 \pm 0.07 \\
1.67 \pm 0.12 \\
2.74 \pm 0.12 \\
2.85 \pm 0.34 \\
3.76 \pm 0.22 \\
3.71 \pm 0.18 \\
4.96 \pm 0.30 \\
4.91 \pm 0.25 \\
5.65 \pm 0.31 \\
5.60 \pm 0.31\end{array}$ & $\begin{array}{l}1.68 \pm 0.08 \\
1.67 \pm 0.07 \\
2.71 \pm 0.13 \\
2.74 \pm 0.16 \\
3.74 \pm 0.21 \\
3.70 \pm 0.16 \\
4.90 \pm 0.22 \\
4.95 \pm 0.26 \\
5.61 \pm 0.24 \\
5.60 \pm 0.28\end{array}$ & $\begin{array}{l}1.64 \pm 0.08 \\
1.65 \pm 0.09 \\
2.73 \pm 0.16 \\
2.72 \pm 0.14 \\
3.73 \pm 0.21 \\
3.71 \pm 0.20 \\
5.05 \pm 0.30 \\
4.90 \pm 0.26 \\
5.62 \pm 0.28 \\
5.53 \pm 0.33\end{array}$ & $\begin{array}{l}\overline{1.64} \pm 0.09 \\
\overline{2.72} \pm 0.16 \\
\overline{3.71} \pm 0.19 \\
\overline{4.98} \pm 0.20 \\
\overline{5.56} \pm 0.28\end{array}$ & - \\
\hline
\end{tabular}

Values represent mean latency and standarid deviation, in ms, for 10 subjects. 


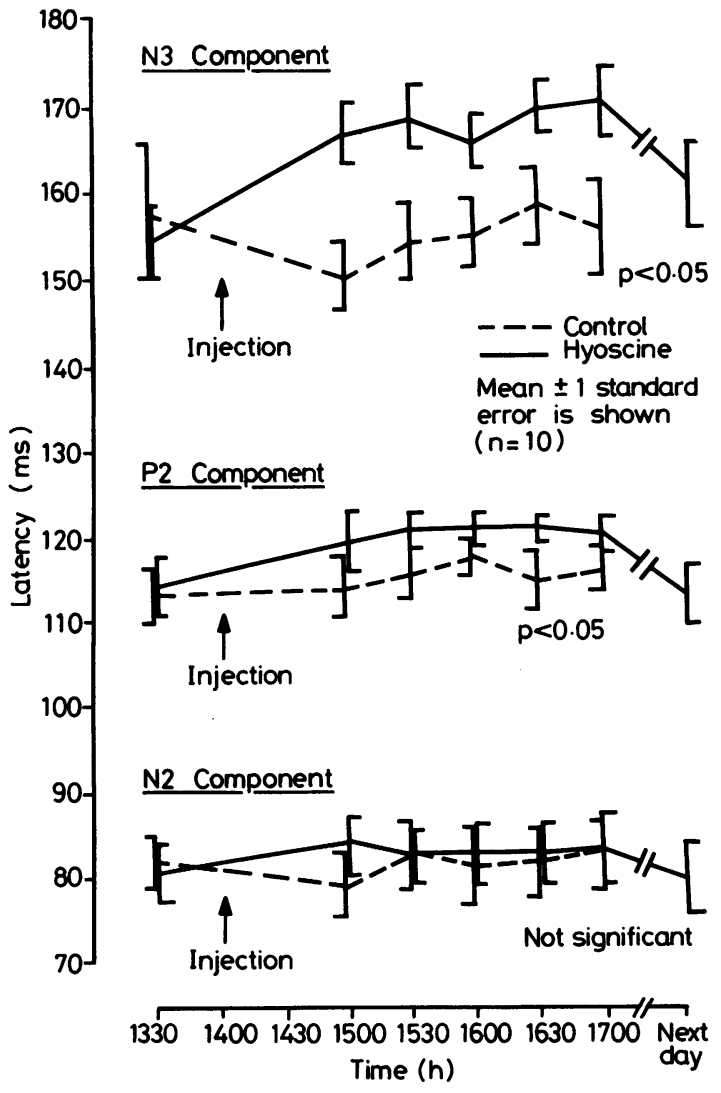

Fig 2 Showing that 0.6 mgm hyoscine hydrobromide produces a significant increase in the latency of the $P 2$ and $N 3$ components of the flash VEP. lation, and a value of 0.05 was used as significance level. The average waveforms for the group were computed on the Pathfinder.

\section{Results}

Latency Administration of $0.6 \mathrm{mg}$ hyoscine hydrobromide produced a slowing of the flash VEP. Figure I shows that this was a progressive effect, being nonsignificant for the $\mathrm{N} 2$ component, but significant at the $5 \%$ level for the $\mathrm{P} 2$ and $\mathrm{N} 3$ components, compared with the control recordings (table 1). However,there was no statistically significant change in the latency of the pattern reversal VEP components (table 2) or the BAEP components (table 3). During the control afternoon, the latency of the flash P2 component increased slightly between 3.00 and $4.00 \mathrm{pm}$. This could be attributable to the effects of boredom or fatigue, although there was no further increase after $4.00 \mathrm{pm}$. This does not affect the significance of the above results, as they represent the difference between the hyoscine and control afternoons.

Amplitude The amplitude of the N2-P2 configuration of the flash VEP was significantly increased by the anticholinergic drug $(p<0.01)$ (table $4)$. There were no significant changes in the amplitude of the pattern reversal VEP (table 5) or the BAEP (table 6) related to the action of the hyoscine.

Waveform Figure 3 shows flash waveforms from $\vec{D}$ one subject, TP, on whom the hyoscine had a particularly marked effect. It can be seen that in this case hyoscine did not significantly affect the N2 com-O ponent, but produced a slowing of the $\mathbf{P} 2$ component and a greater slowing of the $\mathrm{N} 3$ component. This $\overrightarrow{0}$ progressive effect resulted in a broadening of the $\mathrm{P} 2$ component. Subject LA showed a slightly different

Table 4 Amplitude of flash visual evoked potential

\begin{tabular}{|c|c|c|c|c|c|c|c|c|c|c|}
\hline Compor & tent & $1.30 \mathrm{pm}$ & $2.00 \mathrm{pm}$ & $3.00 \mathrm{pm}$ & $3.30 \mathrm{pm}$ & $4.00 \mathrm{pm}$ & $4.30 \mathrm{pm}$ & $5.00 \mathrm{pm}$ & Next Day & $\begin{array}{l}\text { Statistical } \\
\text { significanc }\end{array}$ \\
\hline $\begin{array}{l}\text { N2-P2 } \\
\text { P2-N3 }\end{array}$ & $\begin{array}{l}\text { Control } \\
\text { Hyoscine } \\
\text { Control } \\
\text { Hyoscine }\end{array}$ & $\begin{array}{r}9.5 \pm 3.08 \\
8.9 \pm 3.3 \\
8.3 \pm 3.4 \\
10.0 \pm 4.7\end{array}$ & $\begin{array}{l}\text { Injection of } \\
0.6 \text { mgm hyoscine } \\
\text { hydrobromide } \\
\text { subcutaneously } \\
\text { (Experimental day only) }\end{array}$ & $\begin{array}{r}8.8 \pm 4.0 \\
10.6 \pm 5.0 \\
10.5 \pm 3.0 \\
9.2 \pm 4.1\end{array}$ & $\begin{array}{l}9.0 \pm 4.8 \\
9.9 \pm 4.4 \\
7.9 \pm 4.0 \\
9.7 \pm 3.9\end{array}$ & $\begin{array}{r}9.2 \pm 4.7 \\
10.1 \pm 4.0 \\
9.2 \pm 4.5 \\
10.4 \pm 5.3\end{array}$ & $\begin{array}{r}9.4 \pm 3.7 \\
10.1 \pm 3.8 \\
9.6 \pm 3.4 \\
9.8 \pm 4.2\end{array}$ & $\begin{array}{l}9.7 \pm 3.5 \\
9.5 \pm 4.2 \\
8.2 \pm 2.9 \\
9.6 \pm 4.2\end{array}$ & $\begin{array}{l}\overline{8 \cdot 8} \pm 3 \cdot 9 \\
\overline{8 \cdot 3} \pm 2 \cdot 2\end{array}$ & $\begin{array}{l}\mathrm{p}<0.01 \\
\text { NS }\end{array}$ \\
\hline
\end{tabular}

Values represent mean amplitude and standard deviation, in $\mu \mathrm{V}$, for 10 subjects.

Table 5 Amplitude of pattern reversal visual evoked potential

\begin{tabular}{|c|c|c|c|c|c|c|c|c|c|c|}
\hline Component & & $1.30 \mathrm{pm}$ & $2.00 \mathrm{pm}$ & $3.00 \mathrm{pm}$ & $3.30 \mathrm{pm}$ & $4.00 \mathrm{pm}$ & $4.30 \mathrm{pm}$ & $5.00 \mathrm{pm}$ & Next Day & $\begin{array}{l}\text { Statistica最 } \\
\text { significane }\end{array}$ \\
\hline $\begin{array}{l}\text { N70-P100 } \\
\text { P100-N140 }\end{array}$ & $\begin{array}{l}\text { Control } \\
\text { Hyoscine } \\
\text { Control } \\
\text { Hyoscine }\end{array}$ & $\begin{array}{l}8.2 \pm 4.0 \\
7.2 \pm 4.8 \\
6.3 \pm 1.6 \\
8.7 \pm 5.0\end{array}$ & $\begin{array}{l}\text { Injection of } 0.06 \mathrm{mgm} \\
\text { hyoscine hydrobromide } \\
\text { subcutaneously } \\
\text { (Experimental day only) }\end{array}$ & $\begin{array}{l}6.8 \pm 2.0 \\
6.7 \pm 3.7 \\
5.5 \pm 2.0 \\
7.9 \pm 4.8\end{array}$ & $\begin{array}{l}7.6 \pm 2.8 \\
6.3 \pm 3.4 \\
6.1 \pm 2.2 \\
6.7 \pm 4.4\end{array}$ & $\begin{array}{l}8.5 \pm 3.7 \\
5.6 \pm 3.4 \\
5.7 \pm 2.9 \\
7.5 \pm 4.9\end{array}$ & $\begin{array}{l}7.2 \pm 3.8 \\
6.6 \pm 2.6 \\
5.8 \pm 3.0 \\
7.3 \pm 3.9\end{array}$ & $\begin{array}{l}7 \cdot 0 \pm 3 \cdot 3 \\
7 \cdot 5 \pm 4 \cdot 6 \\
5 \cdot 8 \pm 2 \cdot 1 \\
8 \cdot 6 \pm 5 \cdot 2\end{array}$ & $\begin{array}{l}\overline{7 \cdot 0} \pm 4 \cdot 2 \\
\overline{6 \cdot 3} \pm 1 \cdot 9\end{array}$ & $\begin{array}{l}\text { NS } \\
\text { NS }\end{array}$ \\
\hline
\end{tabular}

Values represent mean amplitude and standard deviation, in $\mu \mathrm{V}$, for 10 subjects. 


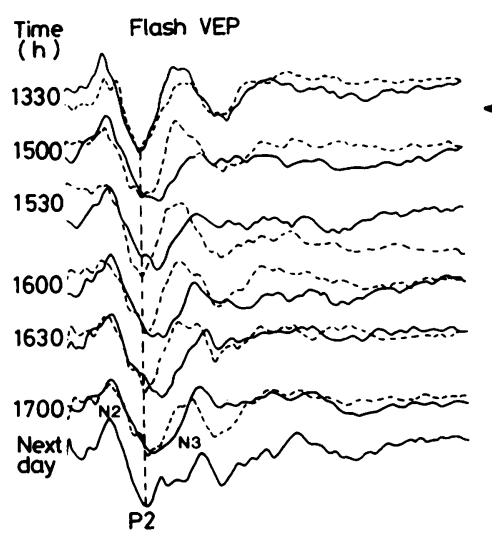

Pattern reversal VEP

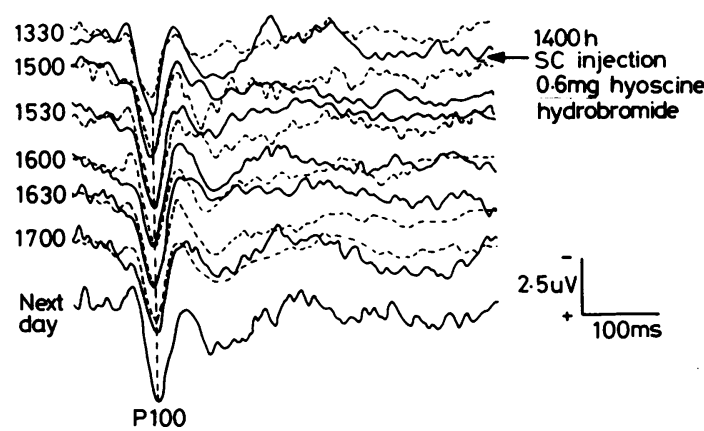

Fig 3 Individual VEP waveforms from subject TP. During maximum effect, the hyoscine produces an increase in the latency of the flash P2 and N3 components which broadens the waveform. The pattern reversal VEP is unaffected.

change in waveform (fig 4). At the maximum effect of the hyoscine (1-1 $1 / 2$ hours after administration) the P2 was triphasic in configuration, indicating that some fibres were affected more than others. The wave returned to its former shape as effect of the drug wore off. These changes in shape varied with the individual, so that there were no overall waveform changes in the group average waveforms (fig 1). However, the
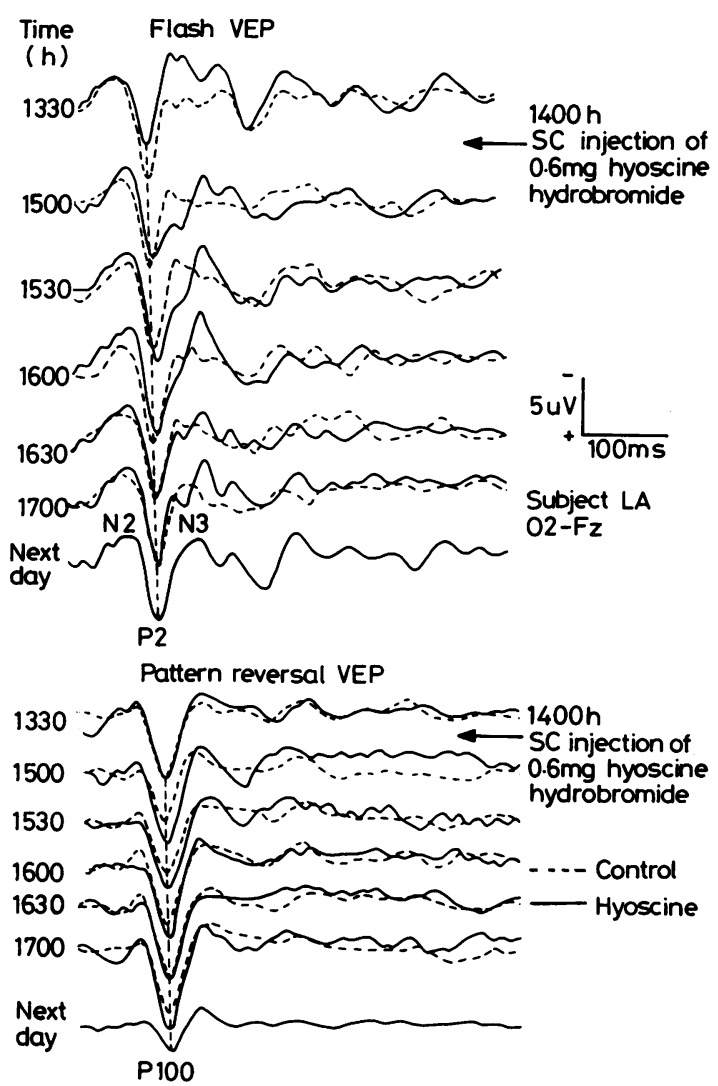

Fig 4 Individual VEP waveforms from subject $L A$. The hyoscine initially produces a broadening of the flash $P 2$ component into a triphasic configuration, indicating that some fibres are affected and some unaffected. The pattern reversal VEP is unaffected.

latency and amplitude increases mentioned above can be clearly seen. Figures 1,3 and 4 show that the hyoscine did not have any effect on the pattern reversal waveforms of these two individuals or the group average.

Subjective effects The subjective effects were all con-

- Table 6 Amplitude of brainstem auditory evoked potential

\begin{tabular}{|c|c|c|c|c|c|c|c|c|c|c|}
\hline \multicolumn{2}{|c|}{ Component } & $1.30 \mathrm{pm}$ & $2.00 \mathrm{pm}$ & $3.00 \mathrm{pm}$ & $3.30 \mathrm{pm}$ & $4.00 \mathrm{pm}$ & $4.30 \mathrm{pm}$ & $5.00 \mathrm{pm}$ & Next Day & $\begin{array}{l}\text { Statistical } \\
\text { significance }\end{array}$ \\
\hline $\begin{array}{l}\text { III } \\
\text { IV }\end{array}$ & $\begin{array}{l}\text { Control } \\
\text { Hyoscine } \\
\text { Control } \\
\text { Hyoscine } \\
\text { Control } \\
\text { Hyoscine } \\
\text { Control } \\
\text { Hyoscine } \\
\text { Control } \\
\text { Hyoscine }\end{array}$ & $\begin{array}{l}0.12 \pm 0.07 \\
0.12 \pm 0.05 \\
0.16 \pm 0.06 \\
0.22 \pm 0.12 \\
0.31 \pm 0.09 \\
0.38 \pm 0.15 \\
0.30 \pm 0.16 \\
0.31 \pm 0.19 \\
0.41 \pm 0.27 \\
0.44 \pm 0.10\end{array}$ & $\begin{array}{l}\text { Injection of } \\
0.6 \text { mgm } \\
\text { hyoscine } \\
\text { hydrobromide } \\
\text { subcutaneously } \\
\text { (Experimental } \\
\text { day only) }\end{array}$ & $\begin{array}{l}0.16 \pm 0.11 \\
0.11 \pm 0.07 \\
0.22 \pm 0.12 \\
0.21 \pm 0.13 \\
0.30 \pm 0.12 \\
0.36 \pm 0.11 \\
0.26 \pm 0.14 \\
0.27 \pm 0.20 \\
0.29 \pm 0.10 \\
0.42 \pm 0.14\end{array}$ & $\begin{array}{l}0.17 \pm 0.11 \\
0.11 \pm 0.06 \\
0.18 \pm 0.08 \\
0.17 \pm 0.09 \\
0.35 \pm 0.10 \\
0.33 \pm 0.11 \\
0.29 \pm 0.54 \\
0.31 \pm 0.13 \\
0.40 \pm 0.14 \\
0.37 \pm 0.16\end{array}$ & $\begin{array}{l}0.15 \pm 0.13 \\
0.14 \pm 0.04 \\
0.20 \pm 0.14 \\
0.21 \pm 0.11 \\
0.32 \pm 0.14 \\
0.37 \pm 0.14 \\
0.24 \pm 0.14 \\
0.34 \pm 0.19 \\
0.47 \pm 0.28 \\
0.45 \pm 0.13\end{array}$ & $\begin{array}{l}0.20 \pm 0.14 \\
0.12 \pm 0.07 \\
0.18 \pm 0.11 \\
0.18 \pm 0.09 \\
0.33 \pm 0.11 \\
0.34 \pm 0.16 \\
0.23 \pm 0.13 \\
0.32 \pm 0.18 \\
0.35 \pm 0.13 \\
0.46 \pm 0.18\end{array}$ & $\begin{array}{l}0.13 \pm 0.06 \\
0.12 \pm 0.07 \\
0.20 \pm 0.09 \\
0.20 \pm 0.13 \\
0.29 \pm 0.12 \\
0.34 \pm 0.12 \\
0.28 \pm 0.16 \\
0.32 \pm 0.17 \\
0.40 \pm 0.18 \\
0.41 \pm 0.16\end{array}$ & $\begin{array}{l}\overline{0.17} \pm 0.09 \\
\overline{0.25} \pm 0.20 \\
\overline{0.37} \pm 0.12 \\
\overline{0.32} \pm 0.15 \\
\overline{0.41} \pm 0.16\end{array}$ & $\bar{z}$ \\
\hline
\end{tabular}

Values represent mean amplitude and standard deviation, in $\mu \mathrm{V}$, for 10 subjects. 
sistent with the expected actions of an anticholinergic drug. Most subjects noticed a drying of the mouth and, in some cases, a change in taste or a sensation of air in the oesophagus. The subjects became drowsy but in no case did this affect the fixation of the visual stimuli. A few subjects with high degrees of heterophoria experienced difficulty in the maintenance of binocular vision. However, this did not affect the experiment as monocular fixation was used. The ability to accommodate on the TV screen at $150 \mathrm{~cm}$ was not affected.

\section{Discussion}

The delay of the P2 component of the flash VEP in Alzheimer's disease is now well documented. ${ }^{22} 232526$ This study has shown that administration of a low dose of an anticholinergic agent to normal subjects also produced an increase in the flash P2 and N3 latency. The effect was small owing to the very low dose used, but was significant enough to suggest that the larger flash P2 delays seen in Alzheimer's disease could be explained by the large reductions in cholinergic activity associated with this disease. The increase in the flash N2-P2 amplitude produced by the hyoscine in this study is also found in patients with presenile dementia. ${ }^{23}{ }^{25}$ However, our previous study ${ }^{23}$ indicated that it is the latency rather than the amplitude effect which is specific to dementia.

The coexistence of a pattern VEP of normal latency and a delayed flash VEP in Alzheimer's disease as described by our group is certainly unusual. ${ }^{22} 23$ It could be that the flash P2 component and the pattern reversal VEP reflect similar mechanisms but are generated in different areas of the visual cortex, and that for some reason, Alzheimer's disease only affects the flash P2 generator area. If this were the case, the effect of an anticholinergic agent on normal subjects with no pathology of the brain would be the same for both types of VEP. Alternatively, the findings in Alzheimer's disease could represent a difference in the influence of the cholinergic system on the two types of VEP. In this case it would be expected that in normals the flash and pattern reversal VEP would be affected differently by an anticholinergic agent. Our results show the latter to be the case, indicating that the flash P2 component is more influenced by the cholinergic system than the pattern VEP. The results of our study must have been due to central cholinergic action of the drug for, if they had been caused by peripheral effects alone, the pattern reversal VEP would also have been affected.

These results appear to relate well to current literature on the relationship between the cholinergic system and the visual cortex in normals and patients with Alzheimer's disease. In the rat, the innervation of the occipital cortex and hippocampus arises from the diagonal band of Broca, while the hippocampus is also innervated by neurons with cell bodies in the medial septal nucleus. Cholinergic neurons from the nucleus basalis of Meynert project to the frontal, prefrontal and parietal cortex. ${ }^{920}$ Postmortem studies of human brains with Alzheimer's disease show that the cells in the nucleus basalis of Meynert and the diagonal band of Broca are grossly reduced. ${ }^{92127}$ Physiologically, the diagonal band of Broca and medial septum appear to be connected with learning and recent memory in animals. The learning and memory defects seen in the early stage of Alzheimer's disease would therefore be consistent with pathology in this region. ${ }^{9}$ As the cholinergic neurons of the visual cortex also originate in this area of the brain, abnormalities of the VEP might be related to these reductions in learning and memory. The function of the nucleus basalis of Meynert is not established, but primate research suggests that it could be connected with reward, learning and attention, which might relate to the emotional and cognitive difficulties that develop in Alzheimer's disease. $^{9}$

These subcortical areas are involved in the ascending reticular arousal system, which is believed to be cholinergic. ${ }^{8}$ EEG rhythms, which are believed to originate from this area, are affected by anti cholinergic drugs. ${ }^{2829}$ A study of the effect of hy oscine on the flash VEP of rats concludes that the changes in the VEP are similar to the changes pro $T$ duced by septal lesions. ${ }^{30}$ The authors suggested that $\frac{O}{2}$ as the cholinergic fibres to the visual cortex pass through the septum, the flash VEP changes could be. reflections of changes in diffuse ascending electro $\overrightarrow{0}$ physiological arousal mechanisms.

This leads us to a more specific examination of what is known about the cholinergic activity of the visual cortex in Alzheimer's disease and in normal brains. Postmortem studies of Alzheimer's brains have shown that the enzyme ChAT is significantly reduced in Brodmann's Area $17^{1415}$ and Area $19^{13}$ of the visual cortex, when compared with controls. In normal brains, the cholinergic activity of Area 17 has been found to be lower than other areas of the brain. ${ }^{1531}$ The fibres of the geniculostriate visual pathway are not cholinergic. ${ }^{29}$ This was also shown in studies of the responses of the cells of the cat's visual cortex to cholinergic stimulation by Spehlmann's group. They concluded that the specific neural input to the primary visual cortex (Area 17) is not cholinergic $^{32}$ but that $\mathrm{ACh}$ may function as the synaptic transmitter for reticular input to the visual cortex, or possibly as a non-synaptic neuronal excitant. ${ }^{28}$

Applying these findings to our results, it would appear that the pattern reversal VEP, which is believed to represent the response of the geniculo-striate fibres 
as they reach the primary visual cortex, is not transmitted by cholinergic fibres and is therefore unaffected by the anti-cholinergic drug hyoscine. However, the slowing of the flash VEP that the hyoscine produced implies that the flash VEP not only reflects specific visual inputs to the visual cortex, but is also influenced by non-specific cholinergic arousal mechanisms.

These results indicate that the flash VEP abnormalities found in Alzheimer's disease could be reflecting reductions in cholinergic activity. They also provide evidence to suggest that the flash and pattern VEP reflect different aspects of cortical processing.

We thank Professor GFA Harding and Dr JMS Pearce for reading the manuscript and giving helpful advice. We are also indebted to the 10 volunteer subjects and to Patricia Roberts and Margaret Geddes for typing the manuscript. Dr Christine Wright is funded by the British Foundation for Age Research.

\section{References}

${ }^{1}$ Longo VG. Behavioural and electroencephalographic effects of Atropine and related compounds. Pharmacol Rev 1966;18:2:965-96.

${ }^{2}$ Ostfeld AM, Aruguete A. Central nervous system effects of hyoscine in man. Pharmacol Exp Ther 1962; 137:133-9.

${ }^{3}$ Crow TJ, Grove-White IG. An analysis of the learning deficit following hyoscine administration in man. $\mathrm{Br} J$ Pharmacol 1973;49:322-7.

${ }^{4}$ Drachman DA, Leavitt J. Human memory and the cholinergic system. Arch Neurol 1974;30:113-21.

${ }^{5}$ Drachman DA. Memory, dementia, and the cholinergic system. In: Katzman R, Terry RD, Bick KL. eds. Alzheimer's Disease, Senile Dementia and Related Disorders. New York: Raven Press 1978:141-48.

${ }^{6}$ Sitaram N, Weingartner H, Gillin JC. Human serial learning: enhancement with arecholine and choline and impairment with Scopolamine. Science 1978;201:274-6.

${ }^{7}$ Davis KL, Mohs RC, Tinklenberg JR, Pfefferbaum A, Hollister LE, Kopell BS. Physostigmine: improvement of long-term memory processes in normal humans. Science 1978;201:272-4.

${ }^{8}$ Rossor MN. Neurotransmitters and CNS disease - dementia. Lancet 1982;ii:1200-4.

${ }^{9}$ Coyle JT, Price DL, Delong MR. Alzheimer's disease: a disorder of cortical cholinergic innervation. Science 1983;219:1184-90.

${ }^{10}$ Bowen DM, Smith CB, White P, Davison AN. Neurotransmitter-related enzymes and indices of hypoxia in senile dementia and other abiotrophies. Brain 1976;99:459-96.

${ }^{11}$ Davies P, Maloney AJF. Selective loss of central cholinergic neurons in Alzheimer's disease. Lancet 1976;ii:1403.

12 Perry EK, Perry RH, Blessed G, Tomlinson BE. Necropsy evidence of central cholinergic deficits in senile dementia. Lancet 1977;1:189.

${ }^{13}$ Perry EK, Gibson PH, Blessed G, Perry RH, Tomlinson BE. Neurotransmitter enzyme abnormalities in senile dementia. J Neurol Sci 1977;34:247-65.

${ }^{14}$ Davies P. Neurotransmitter-related enzymes in senile dementia of the Alzheimer type. Brain Res 1979;171: 319-7.

${ }^{15}$ Rossor MN, Garrett NJ, Johnson AL, Mountjoy CQ, Roth M, Iversen LL. A post-mortem study of the cholinergic and GABA systems in senile dementia. Brain 1982;105:313-30.

${ }^{16}$ Davies P. Biochemical changes in Alzheimer's disease senile dementia: Neurotransmitters in senile dementia of the Alzheimer's type. In: Katzman R. eds. Congenital and Acquired Cognitive Disorders. New York: Raven Press 1979:153-66.

${ }^{17}$ Bowen DM, Sims NR, Benton S, et al. Biochemical changes in cortical brain biopsies from demented patients in relation to morphological findings and pathogenesis. In: Corkin S, Davis KL, Growdon JH, Usdin E, Wurtman RJ, eds. Alzheimer's Disease: a Report of Progress. Aging Volume 19. New York: Raven Press 1982:1-8.

${ }^{18}$ Perry EK, Tomlinson BE, Blessed F, Bergmann K, Gibson PH, Perry RH. Correlation of cholinergic abnormalities with senile plaques and mental test scores in senile dementia. Br Med J 1978;ii:1457-9.

${ }^{19}$ Davies P, Verth AH. Regional distribution of muscarinic acetylcholine receptor in normal and Alzheimer's-type dementia brains. Brain Res 1978;138:385-92.

${ }^{20}$ McKinney M, Hedreen J, Coyle JT. Cortical cholinergic innervation: implications for the pathophysiology and treatment of Alzheimer's disease. In: Corkin S, Davis KL, Growdon JH, Usdin E, Wurtman RJ. eds. Alzheimer's Disease: a Report on Progress. Aging Vol. 19: New York: Raven Press 1982.

${ }^{21}$ Whitehouse PJ, Price DL, Struble RG, Clark AW, Coyle JT, Delong MR. Alzheimer's disease and senile dementia: loss of neurons in the basal forebrain. Science 1982;215:1237-9.

${ }^{22}$ Harding GFA, Doggett CE, Orwin A, Smith EJ. Visual evoked potentials in pre-senile dementia. In: Spekreijse H. Apkarian PA. eds. Documenta Ophthalmological Series No. 27. The Hague: Junk Publishers 1981:193-202.

${ }^{23}$ Wright CE, Harding GFA, Orwin A. Pre-senile dementia - the use of the flash and pattern VEP in diagnosis. Electroencephalogr Clin Neurophysiol 1984;57:405-15.

${ }^{24}$ Wright CE, Williams DE, Drasdo N, Harding GFA. The influence of age on the electroretinogram and the visual evoked potential. Documenta Ophthalmologica 1985;59: 365-84.

${ }^{25}$ Visser SL, Stam FC, Tilburg Van W, Velde Op Den Blom Rijke. Visual evoked response in senile and presenile dementia. Electroencephalogr Clin Neurophysiol 1976;40:385-92.

${ }^{26}$ Cosi V, Vitelli E, gozzoli A, Corona M, Ceroni M, Callieco R. Visual evoked potentials in aging of the brain. in: Courjon J, Mauguiere F, Revol M. eds. Clinical Applications of Evoked Potentials in Neurology. New York: Raven Press 1982.

${ }^{27}$ Perry EK, Perry RH. The cholinergic system in Al- 
zheimer's disease. Trends in neuroscience 1982;94:261-2.

${ }^{28}$ Spehlmann R. Acetylcholine and the synaptic transmission of non-specific impulses to the visual cortex. Brain 1971;94:139-50.

${ }^{29}$ Shute CCD, Lewis PR. The ascending cholinergic reticular system: neurocortical olfactory and subcortical projections. Brain 1967;90:497-519.

${ }^{30}$ Mello WF, Schwartzbaum JS. Effects of scopolamine upon behavioural reactivity and visually evoked poten- tial to flashes in rats. J Comp Physiol Psychol 1973;85: 음 3:469-78.

${ }^{31}$ Bowen DM, Sims NR, Lee KAP, Marek KL. Acetylcholine synthesis and glucose oxidation are preserved in human brain obtained shortly after death. Neurosci Lett 1982;31:195-99.

${ }^{32}$ Spehlmann R, Daniels JC, Smathers CC. Acetylcholine 0 and the synaptic transmission of specific impulses to the visual cortex. Brain 1971;94:125-38. 